\title{
Determining Optimum Calcium and Magnesium Sources and Rates for Home Gardeners Growing Vegetables in Potting Media Using Alkaline Irrigation Water
}

\author{
Sarah B. Everhart ${ }^{1,4,7}$, Kathryn K. Fontenot ${ }^{2,5}$, Edward W. Bush ${ }^{3,5}$, \\ and Charles E. Johnson ${ }^{3,6}$
}

AdDitional index words. dolomitic lime, pH, alkalinity, gypsum, Epsom salt, lettuce, cabbage, cauliflower

SumMARY. Home gardeners living in areas with alkaline water sources do not have easy or economically affordable means of acidifying irrigation water for vegetable production. One solution for achieving optimal vegetable yields using alkaline irrigation water is to grow the vegetables in a modified medium. To date, no medium on the retail market suits such growing needs. Therefore, medium recipes with varied levels $\left(0,4\right.$, or $\left.8 \mathrm{lb} / \mathrm{yard}^{3}\right)$ and sources of calcium [dolomitic lime, calcium sulfate $\left(\mathrm{CaSO}_{4}\right)$ ] and magnesium [dolomitic lime, magnesium sulfate $\left.\left(\mathrm{MgSO}_{4}\right)\right]$ were tested using an alkaline irrigation on 'Oakleaf' lettuce (Lactuca sativa), 'Earliana' and 'Salad Delight' cabbage (Brassica olevacea var. capitata), and 'Snow Crown' cauliflower (Brassica olevacea var. botrytis) crops. Additionally, crops were grown in two environments, under a high tunnel and on a nursery yard. High tunnel and nursery yard sites were used to test media performances in the presence of, and eliminating, rainwater to simulate container-grown vegetables growing in both a home garden situation and a commercial greenhouse production situation. The base mix of all media treatments in the study was 80 bark : 20 peat and fertilized with $12 \mathrm{lb} /$ yard $^{3}$ slow-release fertilizer at a rate of $1.8 \mathrm{lb} / \operatorname{yard}^{3}$ nitrogen $(\mathrm{N}), 0.5$ $\mathrm{lb} / \operatorname{yard}^{3}$ phosphorus $(\mathrm{P})$, and $1 \mathrm{lb} /$ yard $^{3}$ potassium $(\mathrm{K})$. This initial fertilizer application was incorporated to each medium before filling containers. Four treatments were tested against a commercially available medium, industry standard (IS) treatment (a commercially available bagged medium), and a control medium [treatment $\mathrm{C}$ (no supplemental calcium or magnesium fertilizer)] by supplementing the base mix with the following fertilizer levels: $4 \mathrm{lb} / \mathrm{yard}^{3}$ each of $\mathrm{CaSO}_{4}$ and $\mathrm{MgSO}_{4}$ (treatment 1); $4 \mathrm{lb} /$ yard $^{3}$ dolomitic lime (treatment 2); $4 \mathrm{lb} / \mathrm{yard}^{3}$ each of dolomitic lime, $\mathrm{CaSO}_{4}$, and $\mathrm{MgSO}_{4}$ (treatment 3); $8 \mathrm{lb} / \mathrm{yard}^{3}$ dolomitic lime (treatment 4). Media treatments 1 through 4 outperformed the IS and $\mathrm{C}$ media treatments in nearly all crops. All crops grown on the nursery yard, and cabbage grown under the high tunnel, had greater yields when grown in medium treatment 3 , compared with the IS and $\mathrm{C}$ media treatments $(P \leq 0.05)$. All crops grown in medium treatment 2 on the nursery yard produced greater yields than the IS and C media treatments $(P \leq 0.05)$.

$\mathrm{I}$

$\mathrm{n}$ the southeastern United States, pine bark is commonly combined with peat to manufacture gardening

Mention of trade names or commercial products in this article is solely for the purpose of providing specific information and does not imply recommendation or endorsement.

${ }^{1}$ Jefferson Parish, LSU AgCenter, 1221 Elmwood Park Boulevard, Suite 300, Jefferson, LA 70123

${ }^{2}$ School of Plant, Environmental, and Soil Sciences, LSU AgCenter, 155 JC Miller, Baton Rouge, LA 70803

${ }^{3}$ School of Plant, Environmental, and Soil Sciences, LSU AgCenter, 137 JC Miller, Baton Rouge, LA 70803

${ }^{4}$ County Agent.

${ }^{5}$ Assistant Professor.

${ }^{6}$ Professor

${ }^{7}$ Corresponding author. E-mail: cseverhartfamily@ gmail.com.

doi: 10.21273/HORTTECH03316-16

108
Biernbaum, 1997). However, unamended pine bark and peat-based media are too acidic for many container crops. According to Wright et al. (1999), the initial $\mathrm{pH}$ of pine bark ranges from 4.0 to 5.5 , depending on age, source, and other factors. Therefore, it is standard for retail media producers to add lime to their mixes. The addition of lime helps balance $\mathrm{pH}$ and supplies calcium and magnesium, essential elements for plant growth. Liming rates vary based on plant species, medium components, and lime particle size. Lime should be incorporated to increase the medium $\mathrm{pH}$ to a range of 5.5 and 6.4 (Argo and Biernbaum, 1996) for most crops; however, no studies have reported liming rates specific to vegetable crops produced in containers.

Alkalinity, caused by carbonates and bicarbonates (Handreck and Black, 2002), in irrigation water can cause increased medium $\mathrm{pH}$ and decreased nutrient availability (Wickerson et al., 1996). Low levels of alkalinity should be present to buffer a medium solution from rapid $\mathrm{pH}$ changes (Greenlee et al., 2009; Valdez-Aguilar, 2004). Recommendations for ideal bicarbonate in irrigation water vary from a low range $0-75 \mathrm{mg} \cdot \mathrm{L}^{-1}$ to a high range $61-122 \mathrm{mg} \cdot \mathrm{L}^{-1}$ (Biernbaum, 1994; Dole, 1994; Nelson, 1998; Peterson and Kramer, 1991), but alkalinity problems exist when levels are too high. Moderate electrical conductivity (EC) for irrigation water is between 0.75 and $3 \mathrm{mg} \cdot \mathrm{L}^{-1}$; water above $3 \mathrm{mg} \cdot \mathrm{L}^{-1}$ should not be used (Bauder et al., 2014). In 1984, Ludwig and Peterson reported that $80.8 \%$ of water samples tested within the United States exceeded desirable alkalinity.

Baton Rouge, LA, municipal water measured $\mathrm{pH} 8.6$ and EC 0.38 $\mathrm{mS} \cdot \mathrm{cm}^{-1}$ during this study. Creating aeration, water holding capacity, and cation exchange capacity (Argo and

media. The combination of peatmoss and pine bark provide good medium

\begin{tabular}{llll}
\hline $\begin{array}{l}\text { Units } \\
\begin{array}{l}\text { To convert U.S. } \\
\text { to SI, multiply by }\end{array}\end{array}$ & U.S. unit & SI unit & $\begin{array}{l}\text { To convert SI to } \\
\text { U.S., multiply by }\end{array}$ \\
\hline 0.0731 & $\mathrm{fl} \mathrm{oz} / \mathrm{acre}$ & $\mathrm{L} \cdot \mathrm{ha}^{-1}$ & 13.6840 \\
0.0283 & $\mathrm{ft}^{3}$ & $\mathrm{~m}^{3}$ & 35.3147 \\
3.7854 & gal & $\mathrm{L}$ & 0.2642 \\
2.54 & inch $(\mathrm{es})$ & $\mathrm{cm}$ & 0.3937 \\
25.4 & inch $(\mathrm{es})$ & $\mathrm{mm}$ & 0.0394 \\
0.5933 & $\mathrm{lb} / \mathrm{yard}$ & $\mathrm{kg} \cdot \mathrm{m}^{-3}$ & 1.6856 \\
1 & $\mathrm{mmho} / \mathrm{cm}$ & $\mathrm{dS} \cdot \mathrm{m}^{-1}$ & 1 \\
1 & $\mathrm{mmho} / \mathrm{cm}$ & $\mathrm{mS} \cdot \mathrm{cm}^{-1}$ & 1 \\
28.3495 & $\mathrm{Oz}$ & $\mathrm{g}$ & 0.0353 \\
1 & $\mathrm{ppm}$ & $\mathrm{mg} \cdot \mathrm{L}^{-1}$ & 1 \\
0.7646 & $\mathrm{yard}$ & $\mathrm{m}$ & 1.3080 \\
$\left({ }^{\circ} \mathrm{F}-32\right) \div 1.8$ & ${ }^{\circ} \mathrm{F}$ & ${ }^{\circ} \mathrm{C}$ & $\left({ }^{\circ} \mathrm{C} \times 1.8\right)+32$
\end{tabular}


a specialized medium for vegetable container production targeting homeowners in areas of alkaline irrigation water, such as Baton Rouge, would enable production of highquality vegetables despite irrigation water $\mathrm{pH}$ and alkalinity issues. The objective of this study was to find a suitable medium recipe for container production of lettuce, cabbage, and cauliflower irrigated with alkaline water.

\section{Materials and methods}

ExPERIMENTAL DESIGN. This experiment was conducted at the Louisiana State University Agricultural Center (LSU AgCenter) Botanic Gardens in Baton Rouge. Two experimental sites within the property were used: a nursery yard arranged in a randomized block design with overhead irrigation $(2.5 \mathrm{gal} / \mathrm{min})$ also exposed to rainwater, and a high tunnel arranged in a randomized block design with drip irrigation $(2 \mathrm{gal} / \mathrm{h})$ not exposed to rainwater. The purpose of including two sites, under cover (high tunnel) and without cover (nursery yard), within the LSU AgCenter Botanic Gardens property was to simulate two environments, a commercial high tunnel or greenhouse, and a homeowner's uncovered patio. Fall crops studied included lettuce, cabbage, and cauliflower. Lettuce, cabbage, and cauliflower were grown in six media treatments. Each medium treatment/ crop combination was replicated 10 times per experimental site, and each planting was replicated over two planting dates, $\approx 2$ months apart.

Media treatments. The six media treatments used in this study contained 0,4 , or $8 \mathrm{lb} /$ yard $^{3}$ rates of dolomitic lime and 0 or $4 \mathrm{lb} /$ yard $^{3}$ rates of $\mathrm{CaSO}_{4}[23 \%$ calcium $(\mathrm{Ca})$
(Soft Pelletized Gypsum; MK Minerals, Wamego, KS)] and $\mathrm{MgSO}_{4}$ $[13.7 \%$ magnesium $(\mathrm{Mg})$ (product 24592; Graco Fertilizer Co., Cario, GA)] (Table 1). The industry standard medium was a commercially available bagged medium (All Purpose Potting Mix; Scott's MiracleGro, Marysville, $\mathrm{OH}$ ) selected because of its notoriety among home gardeners. The control and media treatments $\mathrm{l}$ to 4 were mixed at the LSU AgCenter Botanic Gardens and contained $80 \%$ bark $(5 / 8$-inch screened, partially composted; Phillip's Bark, Brookhaven, MS) and 20\% peat (Ferti-Lome Pure Canadian Sphagnum Peat Moss; Lambert Peat Moss, Eugene, OR) and fertilized with slow-release fertilizer $12 \mathrm{lb} /$ yard $^{3}$ slow-release fertilizer (Osmocote Plus Lo-Start 15-9-11; Everris, Dublin, $\mathrm{OH}$ ) at a rate of $1.8 \mathrm{lb} /$ yard $^{3}$ $\mathrm{N}, 0.5 \mathrm{lb} / \operatorname{yard}^{3} \mathrm{P}$, and $1 \mathrm{lb} / \operatorname{yard}^{3} \mathrm{~K}$. Additional components were not added to the control medium. Medium treatment 1 contained an additional $4 \mathrm{lb} /$ yard $^{3}$ each of $\mathrm{CaSO}_{4}$ and $\mathrm{MgSO}_{4}$. Medium treatment 2 contained an additional $4 \mathrm{lb} /$ yard $^{3}$ dolomitic lime $[17.5 \% \mathrm{Ca}, 10.1 \% \mathrm{Mg}$ (Pelletized Dolomitic Limestone; MK Minerals)]. Medium treatment 3 contained an additional $4 \mathrm{lb} /$ yard $^{3}$ each of dolomitic lime, $\mathrm{CaSO}_{4}$, and $\mathrm{MgSO}_{4}$. Medium treatment 4 contained an additional $8 \mathrm{lb} / \mathrm{yard}^{3}$ dolomitic lime.

Media treatments were mixed in 1-yard ${ }^{3}$ batches. Standard 3-gal, blow-mold-injection black pots were filled with $0.45 \mathrm{ft}^{3}$ media. Pots were placed on 18-inch centers under the high tunnel and on the nursery yard and watered to saturate media before transplanting the fall vegetables. Additional medium was not added to individual containers after settling. Three pots of each media treatment were used to measure initial $\mathrm{pH}$ and EC according to the Virginia Tech Extraction Method (Wright, 1986). Pots were saturated and leachate collected; $30 \mathrm{~min}$ after collection, $\mathrm{pH}$ and EC measurements were recorded. Media treatment $\mathrm{pH}$ and EC measurements were recorded on the day of media mixing and again 2 weeks later to allow time for the dolomitic lime to react. Unaltered city water was used to irrigate the crops during the study. The city water measured $8.6 \mathrm{pH}$ and $0.38 \mathrm{mS} \cdot \mathrm{cm}^{-1}$. The three fall crops evaluated in this study included 'Oakleaf' lettuce and 'Snow Crown' cauliflower. 'Earliana' cabbage was used for the first planting and 'Salad Delight' cabbage for the second planting because 'Earliana' seedlings were not available. Seeds of all crops were planted on 15 Nov. (first planting replication) and again on $15 \mathrm{Feb}$. (second planting replication) into a commercial soilless substrate (Sunshine Professional Growing Mix 3; Sun Gro Horticulture, Agawam, MA) in 98-count plug trays and grown in a greenhouse with greenhouse average temperatures ranging from $65^{\circ} \mathrm{F}$ (night) to $80{ }^{\circ} \mathrm{F}$ (day). Seedlings were fertilized with $24 \mathrm{~N}-$ $3.5 \mathrm{P}-13.3 \mathrm{~K}$ liquid fertilizer (Water Soluble All Purpose Plant Food; Scott's Miracle-Gro) at 1 tablespoon per 3-gal container, using 1 gal water as a carrier. Thirty-nine days after seeding, vegetables were transplanted into prefilled pots, one seedling per 3gal container. Plants that did not survive transplant due to cold weather conditions were replaced within the first $7 \mathrm{~d}$ after transplanting. Fewer than 10 plants of all vegetables combined were replaced per planting replication.

Table 1. Media treatments and ingredients used in a 2012-13 alkaline irrigation vegetable media study completed at the Louisiana State University Agricultural Center Botanic Gardens, Baton Rouge, LA.

\begin{tabular}{|c|c|c|}
\hline $\begin{array}{l}\text { Media } \\
\text { treatment }\end{array}$ & Base mix & Fertilizer added $^{\mathrm{z}}$ \\
\hline IS & All Purpose Potting Mix (Scott's Miracle-Gro) & None \\
\hline $\mathrm{C}$ & 80 bark : 20 peat ratio and $1.8 \mathrm{lb} /$ yard $^{3} \mathrm{~N}, 0.5 \mathrm{lb} /$ yard $^{3} \mathrm{P}$, and $1 \mathrm{lb} /$ yard $^{3} \mathrm{~K}$ & None \\
\hline 1 & 80 bark : 20 peat ratio and $1.8 \mathrm{lb} /$ yard $^{3} \mathrm{~N}, 0.5 \mathrm{lb} /$ yard $^{3} \mathrm{P}$, and $1 \mathrm{lb} /$ yard $^{3} \mathrm{~K}$ & $4 \mathrm{lb} /$ yard $^{3} \mathrm{CaSO}_{4}$ and $\mathrm{MgSO}_{4}$ \\
\hline 2 & 80 bark : 20 peat ratio and $1.8 \mathrm{lb} /$ yard $^{3} \mathrm{~N}, 0.5 \mathrm{lb} /$ yard $^{3} \mathrm{P}$, and $1 \mathrm{lb} /$ yard $^{3} \mathrm{~K}$ & $4 \mathrm{lb} /$ yard $^{3}$ dolomitic lime \\
\hline 3 & 80 bark : 20 peat ratio and $1.8 \mathrm{lb} /$ yard $^{3} \mathrm{~N}, 0.5 \mathrm{lb} / \operatorname{yard}^{3} \mathrm{P}$, and $1 \mathrm{lb} / \operatorname{yard}^{3} \mathrm{~K}$ & $\begin{array}{l}4 \mathrm{lb} / \text { yard }^{3} \text { dolomitic lime, } \mathrm{CaSO}_{4} \text {, } \\
\text { and } \mathrm{MgSO}_{4}\end{array}$ \\
\hline
\end{tabular}

$\mathrm{IS}=$ industry standard; $\mathrm{C}=$ control; $\mathrm{N}=$ nitrogen $; \mathrm{P}=$ phosphorus; $\mathrm{K}=$ potassium.

${ }^{\mathrm{z}} \mathrm{lb} / \mathrm{yard}^{3}=0.5933 \mathrm{~kg} \cdot \mathrm{m}^{-3}$. 
Containers were watered twice daily at 10-min increments using one dripper per pot. Seedlings were fertilized with $24 \mathrm{~N}-3.5 \mathrm{P}-13.3 \mathrm{~K}$ liquid fertilizer at $\mathrm{l}$ tablespoon per 3-gal container, using l-gal of water as a carrier. Pesticides were used as needed and included $1.5 \mathrm{fl} \mathrm{oz} /$ acre malathion (Spectracide Malathion Insect Spray Concentrate; Chemsico, St. Louis, MO), $30 \mathrm{~kg} /$ acre metaldehyde (Deadline M-Ps Mini Pellets; AMVAC Chemical Corporation, Los Angeles, CA), and $65 \mathrm{fl} \mathrm{oz} /$ acre Bacillus thuringiensis (Thuricide; Bonide Produces Inc., Oriskany, $\mathrm{NY}), 65 \mathrm{fl} \mathrm{oz} /$ acre to control, aphids (Aphis sp.), slugs (Deroceras sp.), and worms (Lepidoptera). Days to harvest after transplanting for each crop are reported in Table 2. Precipitation (millimeters), relative humidity (percent), and temperature (degrees Celsius) were recorded hourly and reported on a monthly basis (Fig. 1).

Whole lettuce plants were harvested, cut even with the soil line, and fresh weight (grams) were recorded. Cabbage and cauliflower heads were harvested, and fresh weight (grams) were recorded. The aboveground plant material was dried at $85^{\circ} \mathrm{F}$ in a 220-V forced air oven (SM028-2; Shel Laboratory Cornelius, OR) for 3 weeks, after which dry weights were recorded.

After the fall plants were harvested, spring plants were then placed into the same pots. Media treatments in containers were not replaced for spring crops. Containers originally planted with lettuce were replanted with tomato (Solanum lycopersicum). Containers originally planted with cabbage were replanted with cucumber (Cucumis sativus). Containers originally planted with cauliflower were replanted with bell pepper ( $\mathrm{Cap}$ sicum annuum). Spring crop data are not shown. Leachate analysis for final $\mathrm{pH}$ and $\mathrm{EC}$ were recorded using an average of three pots per media treatment and per crop (lettuce, cabbage, and cauliflower originally planted pots) totaling nine pots of each media/crop combination both on the nursery yard and under the high tunnel. The leachates were collected using the Virginia Tech Extraction Method. The final EC and $\mathrm{pH}$ analysis was collected after both the fall and spring plants were harvested from pots.
Data Analysis. Data were analyzed with SAS software (version 9.3; SAS Institute, Cary, NC) at a $0.05 \%$ error rate. Proc GLM was used to compare continuous variables based on arithmetic means and standard deviations. A Duncan's multiple range test was performed on all variables of interest for each crop.

\section{Results and Discussion}

MEdia INITIAL AND FINAL $\mathrm{PH}$ AND EC. Immediately after mixing (initial recording), all media treatments were below the sufficient $\mathrm{pH}$ range of 5.5 to 6.4 (Argo and Biernbaum, 1996). After 2 weeks, medium 4 remained below the $\mathrm{pH}$ sufficiency range. All media treatments, except the IS, were below the recommended maximum EC of $2 \mathrm{dS} \cdot \mathrm{m}^{-1}$ (Bilderback, 2001) at the initial measurement. After 2 weeks, media treatments C, 2,

Table 2. Days from transplant to harvest for fall crops grown on a nursery yard and under a high tunnel using alkaline irrigation in a 2012-13 alkaline irrigation vegetable media study completed at the Louisiana State University Agricultural Center Botanic Gardens, Baton Rouge, LA.

\begin{tabular}{lcccc}
\hline & $\begin{array}{c}\text { Nursery yard } \\
\text { replication } \mathbf{1}^{\mathbf{z}}\end{array}$ & $\begin{array}{c}\text { High-tunnel } \\
\text { replication 1 }\end{array}$ & $\begin{array}{c}\text { Nursery yard } \\
\text { replication 2 }\end{array}$ & $\begin{array}{c}\text { High tunnel } \\
\text { replication 2 }\end{array}$ \\
\cline { 2 - 5 } Crop & 47 & Time from transplant to harvest (d) & \\
\hline Lettuce & 80 & 40 & 44 & 35 \\
Cabbage & 87 & 78 & 70 & 68 \\
Cauliflower & 87 & 62 & 66 \\
\hline
\end{tabular}

${ }^{\mathrm{z}}$ Crops grown on the nursery yard were irrigated daily with alkaline irrigation and exposed to rainwater throughout the growing season; high-tunnel crops were not exposed to rainwater.

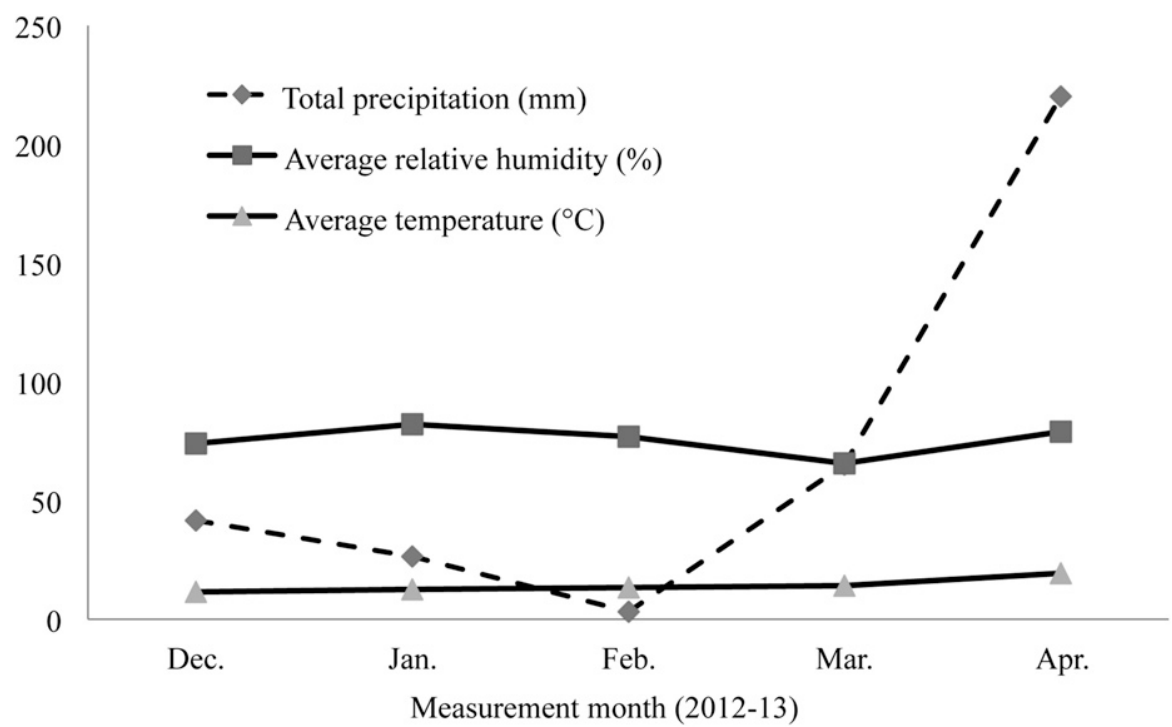

Fig. 1. Monthly total precipitation, average relative humidity, and average outdoor air temperature where at the Louisiana State University Agricultural Center Botanic Gardens, Baton Rouge, LA, throughout the course of a 2012-13 alkaline irrigation vegetable media study; $1 \mathrm{~mm}=0.0394$ inch $\left(1.8 \times{ }^{\circ} \mathrm{C}\right)+32={ }^{\circ} \mathrm{F}$. 
before plants were introduced to media to allow the addition of lime to particular medium treatments to begin reacting. Final recordings were measured after fall and spring plants had been planted in the containers. Spring crop data are not reported. The same pots with the same medium (not removed after fall crops were harvested was used for the spring crop planting). Overall, $\mathrm{pH}$ and EC measurements were acceptable for media treatments C, IS, 1, 2, 3, and 4 for home gardener use.

ENVIRONMENTAL CONDITIONS. Relative humidity and average temperature remained constant between December and April. However, on the nursery yard, precipitation decreased from December to February and increased in March and April (Fig. 1). The increase in precipitation during the second planting replication may have affected media treatments growing on the nursery yard. During the second planting replication, medium treatment 1 did not produce lettuce with as much edible biomass as produced in the same medium treatment in the first replication.

NURSERY YARD. Media treatments 2 and 3 produced higher fresh weights (edible portion of lettuce, cabbage, and cauliflower heads) during both planting replications as

Table 3. Initial and final leachate $\mathrm{pH}$ and electrical conductivity (EC) of media treatments amended with calcium and magnesium fertilizer and watered with alkaline irrigation water in a 2012-13 alkaline irrigation vegetable media study completed at the Louisiana State University Agricultural Center Botanic Gardens, Baton Rouge, LA.

\begin{tabular}{|c|c|c|c|c|c|c|c|c|}
\hline \multirow[b]{3}{*}{ Treatment $^{\mathrm{z}}$} & \multicolumn{4}{|c|}{ Avg preplanting data } & \multicolumn{4}{|c|}{ Avg final data ${ }^{x}$} \\
\hline & \multicolumn{2}{|r|}{ Initial } & \multicolumn{2}{|r|}{ Week 2} & \multicolumn{2}{|c|}{ Final nursery yard } & \multicolumn{2}{|c|}{ Final high tunnel } \\
\hline & $\mathrm{pH}$ & $\mathrm{EC}\left(\mathrm{mS} \cdot \mathrm{cm}^{-1}\right)^{\mathrm{w}}$ & $\mathrm{pH}$ & $\mathrm{EC}\left(\mathrm{mS} \cdot \mathrm{cm}^{-1}\right)$ & $\mathrm{pH}$ & $\mathrm{EC}\left(\mathrm{mS} \cdot \mathrm{cm}^{-1}\right)$ & $\mathrm{pH}$ & $\mathrm{EC}\left(\mathrm{mS} \cdot \mathrm{cm}^{-1}\right)$ \\
\hline $\mathrm{C}$ & $5.0 \mathrm{a}$ & $0.24 \mathrm{c}$ & $4.3 \mathrm{de}$ & $1.09 \mathrm{c}$ & $5.2 \mathrm{~d}$ & $0.33 \mathrm{ab}$ & $6.1 \mathrm{c}$ & $0.34 \mathrm{c}$ \\
\hline 1 & $4.2 \mathrm{c}$ & $1.00 \mathrm{~b}$ & $4.1 \mathrm{e}$ & $2.29 \mathrm{~b}$ & $6.6 \mathrm{a}$ & $0.31 \mathrm{ab}$ & $6.4 \mathrm{ab}$ & $0.55 \mathrm{a}$ \\
\hline 2 & $4.5 \mathrm{bc}$ & $0.24 \mathrm{c}$ & $4.7 \mathrm{c}$ & $1.01 \mathrm{c}$ & $6.4 \mathrm{ab}$ & $0.43 \mathrm{a}$ & $6.6 \mathrm{a}$ & $0.44 \mathrm{~b}$ \\
\hline
\end{tabular}

${ }^{{ }^{z}}$ Media treatments included base mixture of 80 bark : 20 peat ratio and $1.8 \mathrm{lb} /$ yard $^{3}$ nitrogen, $0.5 \mathrm{lb} /$ yard $^{3}$ phosphorus, and $1 \mathrm{lb} /$ yard $^{3}$ potassium: industry standard $($ IS $)=$ unamended All Purpose Potting Mix (Scott's Miracle-Gro, Marysville, $\mathrm{OH})$; control $(\mathrm{C})=0 \mathrm{lb} /$ yard $^{3}$ dolomitic lime (lime), calcium sulfate $\left(\mathrm{CaSO}_{4}\right)$, and magnesium sulfate $\left(\mathrm{MgSO}_{4}\right)$; treatment $\mathrm{l}=0 \mathrm{lb} / \mathrm{yard}^{3}$ lime and $4 \mathrm{lb} / \mathrm{yard}^{3} \mathrm{CaSO}_{4}$ and $\mathrm{MgSO}_{4}$; treatment $2=4 \mathrm{lb} / \mathrm{yard}^{3}$ lime and $0 \mathrm{lb} / \mathrm{yard}^{3} \mathrm{CaSO}_{4}$ and $\mathrm{MgSO}_{4} ;$ treatment $3=4 \mathrm{lb} / \mathrm{yard}^{3} \mathrm{lime}$, $\mathrm{CaSO}_{4}$, and $\mathrm{MgSO}_{4}$; treatment $4=8 \mathrm{lb} / \mathrm{yard}^{3}$ lime and $0 \mathrm{lb} / \mathrm{yard}^{3} \mathrm{CaSO}_{4}$ and $\mathrm{MgSO}_{4} ; \mathrm{llb} /$ yard $^{3}=0.5933 \mathrm{~kg} \cdot \mathrm{m}^{-3}$.

$\mathrm{y}_{\mathrm{n}}=$ three pots per medium treatment for the initial and week 2 measurements. These measurements were taken before any plants being placed into pots.

$\mathrm{x}_{\mathrm{n}}=$ nine pots per medium treatment for final recordings. Three pots per medium treatment and crop were selected at random for $\mathrm{pH}$ and $\mathrm{EC}$ recording.

${ }^{\mathrm{w}} 1 \mathrm{mS} \cdot \mathrm{cm}^{-1}=1 \mathrm{mmho} / \mathrm{cm}$

${ }^{\vee}$ Means within columns (within planting replication) followed by the same letter are not significantly different according to Duncan's multiple range test $(P \leq 0.05)$.

Table 4. Fresh and dry weight measurements of container-grown lettuce, cabbage, and cauliflower heads at harvest when produced on a nursery yard with calcium- and magnesium-amended organic media, alkaline irrigation, and exposure to rainwater over two planting replications in a 2012-13 alkaline irrigation vegetable media study completed at the Louisiana State University Agricultural Center Botanic Gardens, Baton Rouge, LA.

\begin{tabular}{|c|c|c|c|c|c|c|}
\hline \multicolumn{7}{|c|}{ Planting replication 1} \\
\hline \multirow[b]{2}{*}{ Treatment $^{\mathrm{z}}$} & \multicolumn{2}{|c|}{ Lettuce } & \multicolumn{2}{|c|}{ Cabbage } & \multicolumn{2}{|c|}{ Cauliflower } \\
\hline & Fresh wt $(g)^{y}$ & Dry wt (g) & Fresh wt (g) & Dry wt (g) & Fresh wt (g) & Dry wt $(\mathrm{g})$ \\
\hline $\mathrm{C}$ & $140 \mathrm{~b}$ & $6.6 \mathrm{a}$ & $204.2 \mathrm{c}$ & $12.1 \mathrm{~b}$ & $73.9 \mathrm{~d}$ & $6.4 \mathrm{c}$ \\
\hline 1 & $191 \mathrm{a}$ & $7.9 \mathrm{a}$ & $456.1 \mathrm{ab}$ & $30.1 \mathrm{a}$ & $277.3 \mathrm{bc}$ & $24.8 \mathrm{~b}$ \\
\hline 2 & $206 a$ & $8.8 \mathrm{a}$ & $530.4 \mathrm{a}$ & $32.1 \mathrm{a}$ & $358.7 \mathrm{ab}$ & $28.1 \mathrm{ab}$ \\
\hline
\end{tabular}

\begin{tabular}{|c|c|c|c|c|c|c|}
\hline \multirow[b]{2}{*}{ Treatment } & \multicolumn{2}{|c|}{ Lettuce } & \multicolumn{2}{|c|}{ Cabbage } & \multicolumn{2}{|c|}{ Cauliflower } \\
\hline & Fresh wt (g) & Dry wt (g) & Fresh wt (g) & Dry wt (g) & Fresh wt (g) & Dry wt $(\mathrm{g})$ \\
\hline IS & $316 \mathrm{~b}$ & $12.4 \mathrm{a}$ & $277.6 \mathrm{c}$ & $25.6 \mathrm{c}$ & $173.5 \mathrm{c}$ & $14.4 \mathrm{c}$ \\
\hline 1 & $251 \mathrm{c}$ & $8.9 \mathrm{~b}$ & $414.3 \mathrm{bc}$ & $27.1 \mathrm{c}$ & $276.8 \mathrm{~b}$ & $24.3 \mathrm{~b}$ \\
\hline 2 & $371 \mathrm{a}$ & $13.5 \mathrm{a}$ & $455.9 \mathrm{ab}$ & $34.9 \mathrm{ab}$ & $289.0 \mathrm{~b}$ & $23.5 \mathrm{~b}$ \\
\hline 3 & $374 a$ & $12.6 \mathrm{a}$ & $609.5 \mathrm{a}$ & $38.8 \mathrm{a}$ & $437.2 \mathrm{a}$ & $32.3 \mathrm{a}$ \\
\hline
\end{tabular}

${ }^{\mathrm{z}}$ Media treatments included base mixture of 80 bark : 20 peat ratio and $1.8 \mathrm{lb} / \mathrm{yard}^{3}$ nitrogen, $0.5 \mathrm{lb} / \mathrm{yard}^{3}$ phosphorus, and $1 \mathrm{lb} /$ yard $^{3}$ potassium: industry standard (IS) $=$ unamended All Purpose Potting Mix (Scott's Miracle-Gro, Marysville, $\mathrm{OH}$ ); control $(\mathrm{C})=0 \mathrm{lb} / \mathrm{yard}^{3}$ dolomitic lime (lime), calcium sulfate $\left(\mathrm{CaSO}_{4}\right)$, and magnesium sulfate $\left(\mathrm{MgSO}_{4}\right)$; treatment $\mathrm{l}=0 \mathrm{lb} /$ yard $^{3}$ lime and $4 \mathrm{lb} / \mathrm{yard}^{3} \mathrm{CaSO}_{4}$ and $\mathrm{MgSO}_{4}$; treatment $2=4 \mathrm{lb} /$ yard $^{3}$ lime and $0 \mathrm{lb} / \mathrm{yard}^{3} \mathrm{CaSO}_{4}$ and $\mathrm{MgSO}_{4} ;$ treatment $3=4 \mathrm{lb} / \mathrm{yard}^{3} \mathrm{lime}$, $\mathrm{CaSO}_{4}$, and $\mathrm{MgSO}_{4}$; treatment $4=8 \mathrm{lb} / \mathrm{yard}^{3}$ lime and $0 \mathrm{lb} / \mathrm{yard}^{3} \mathrm{CaSO}_{4}$ and $\mathrm{MgSO}_{4} ; \mathrm{l} \mathrm{lb} / \mathrm{yard}^{3}=0.5933 \mathrm{~kg} \cdot \mathrm{m}^{-3}$.

${ }^{\mathrm{y}} \mathrm{lg}=0.0353 \mathrm{oz}$.

${ }^{x}$ Means within columns (and within planting replication) having different letters are significantly different according to Duncan's multiple range test $(P \leq 0.05)$. 
compared with the IS and C media treatments for crops grown on the nursery yard. Medium treatment 3 produced significantly greater cauliflower edible biomass fresh weight than medium treatment 2 on the second planting replication. Medium treatment 4 produced greater fresh weight than the IS and $\mathrm{C}$ media for cabbage and cauliflower crops grown on the nursery yard, but it did not produce greater yields than media treatments 2 and 3 for either crop. Dry weights of cauliflower grown in media 3 and 4 were significantly greater than the IS and C media. Lettuce and cabbage dry weights were not consistently greater than the IS and C in any treatment in either planting replication, but dry weights for media treatments 2,3 , and 4 were greater than or equal to the IS and C media for both dates (Table 4). These results suggest that an optimum vegetable medium for growing fall crops under alkaline irrigation conditions, and exposed to rainwater, would contain $4 \mathrm{lb} /$ yard $^{3}$ of dolomitic lime and that additional $\mathrm{CaSO}_{4}$ and $\mathrm{MgSO}_{4}$ is optional as plant growth in media treatments 2 and 3 were similar but not different from medium treatment 4 . The results from the nursery yard are more applicable to homeowner vegetable production, as most homeowners rely on irrigation water to supplement natural rainwater, especially when growing vegetables in small containers. Many home gardeners do not grow their vegetable containers in closed high tunnel or greenhouse environments.

High tunnel. Cabbage produced in media treatments 1 and 3 produced significantly greater fresh weight than the IS and C media treatments in the first replication. Cabbage produced in media treatments 1,2 , and 3 produced significantly more dry weight than media treatments IS and C in the first replication. In the second replication, cabbage growing in media treatments 1 , 2 , and 3 produced greater fresh and dry weight than cabbages growing in media treatments IS and C. Cauliflower growing in media treatments $1,2,3$, and 4 had greater fresh and dry weight than cauliflower growing in medium treatment $\mathrm{C}$ in both replications of the study. Lettuce and cauliflower dry weights were not consistently greater than the IS and $\mathrm{C}$ in any media treatment, but all media treatments were greater than or equal to the IS and C treatments (Table 5).

\section{Conclusions}

This research suggests homeowners seeking optimum fresh yields of lettuce, cabbage, and cauliflower in outdoor areas such as patio gardens using alkaline irrigation water will benefit from growing in a potting medium using the same recipe as our media treatments 2,3 , or 4 . The optimum medium recipe based on these results would consist of $80 \%$ bark and $20 \%$ peat amended with actual $\mathrm{N}-\mathrm{P}-\mathrm{K}$ rate of $1.8 \mathrm{lb} /$ yard $^{3}$ $\mathrm{N}, 0.5 \mathrm{lb} /$ yard $^{3} \mathrm{P}$, and $\mathrm{l} \mathrm{lb} /$ yard $^{3} \mathrm{~K}$ plus $4 \mathrm{lb} /$ yard $^{3}$ each of dolomitic lime, $\mathrm{CaSO}_{4}$, and $\mathrm{MgSO}_{4}$. There are limited bagged media sources available for vegetable production in containers that do not require mixing in at least $50 \%$ native or top soil. As such, media are not currently available, we recommend media manufactures or local plant nurseries to mix and sell a bagged medium using the above recipe to help homeowners in areas with high $\mathrm{pH}$ irrigation water to achieve optimal results when growing vegetables in container on their porches. Further marketing studies would be beneficial to determine

Table 5. Fresh and dry weight measurements of container-grown lettuce, cabbage, and cauliflower heads at harvest when produced under a high tunnel with calcium- and magnesium-amended organic media and alkaline irrigation in a $2012-13$ alkaline irrigation vegetable media study completed at the Louisiana State University Agricultural Center Botanic Gardens, Baton Rouge, LA.

\begin{tabular}{|c|c|c|c|c|c|c|}
\hline \multicolumn{7}{|c|}{ Planting replication 1} \\
\hline \multirow[b]{2}{*}{ Treatment $^{\mathrm{z}}$} & \multicolumn{2}{|c|}{ Lettuce } & \multicolumn{2}{|c|}{ Cabbage } & \multicolumn{2}{|c|}{ Cauliflower } \\
\hline & $\overline{\text { Fresh wt }(g)^{y}}$ & Dry wt (g) & Fresh wt (g) & Dry wt (g) & Fresh wt (g) & Dry wt (g) \\
\hline $\mathrm{C}$ & $153 \mathrm{c}$ & $8.1 \mathrm{~b}$ & $490.2 \mathrm{~d}$ & $23.2 \mathrm{c}$ & $53.3 \mathrm{c}$ & $4.4 \mathrm{c}$ \\
\hline 1 & $265 \mathrm{a}$ & $11.3 \mathrm{a}$ & $951.5 \mathrm{~b}$ & $47.4 \mathrm{a}$ & $416.8 \mathrm{ab}$ & $28.3 \mathrm{~b}$ \\
\hline 2 & $215 \mathrm{ab}$ & $9.3 \mathrm{ab}$ & $833.5 \mathrm{bc}$ & $43.0 \mathrm{a}$ & $426.2 \mathrm{ab}$ & $32.4 \mathrm{ab}$ \\
\hline & & & ting replicatio & & & \\
\hline
\end{tabular}

\begin{tabular}{|c|c|c|c|c|c|c|}
\hline \multirow[b]{2}{*}{ Treatment } & \multicolumn{2}{|c|}{ Lettuce } & \multicolumn{2}{|c|}{ Cabbage } & \multicolumn{2}{|c|}{ Cauliflower } \\
\hline & Fresh wt (g) & Dry wt (g) & Fresh wt (g) & Dry wt (g) & Fresh wt (g) & Dry wt $(g)$ \\
\hline IS & $200 \mathrm{c}$ & $8.7 \mathrm{bc}$ & $320.4 \mathrm{~b}$ & $20.3 \mathrm{~b}$ & $205.4 \mathrm{bc}$ & $13.7 \mathrm{bc}$ \\
\hline 1 & $196 \mathrm{c}$ & $7.9 \mathrm{c}$ & $544.8 \mathrm{a}$ & $35.7 \mathrm{a}$ & $352.7 \mathrm{a}$ & $22.7 \mathrm{a}$ \\
\hline 2 & $251 \mathrm{ab}$ & $10.0 \mathrm{ab}$ & $642.4 \mathrm{a}$ & $36.5 \mathrm{a}$ & $358.9 \mathrm{a}$ & $24.2 \mathrm{a}$ \\
\hline 3 & $226 b c$ & $10.1 \mathrm{ab}$ & $647.9 \mathrm{a}$ & $36.8 \mathrm{a}$ & $299.6 \mathrm{ab}$ & $17.4 \mathrm{ab}$ \\
\hline
\end{tabular}

${ }^{\mathrm{z}}$ Media treatments included base mixture of 80 bark : 20 peat ratio and $1.8 \mathrm{lb} /$ yard $^{3}$ nitrogen, $0.5 \mathrm{lb} /$ yard $^{3}$ phosphorus, and $\mathrm{l} \mathrm{lb} /$ yard $^{3}$ potassium: industry standard $(\mathrm{IS})=$ unamended All Purpose Potting Mix (Scott's Miracle-Gro, Marysville, $\mathrm{OH})$; control $(\mathrm{C})=0 \mathrm{lb} /$ yard $^{3}$ dolomitic lime (lime), calcium sulfate $\left(\mathrm{CaSO} \mathrm{O}_{4}\right)$, and magnesium sulfate

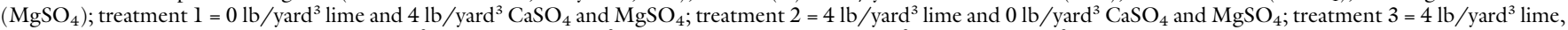
$\mathrm{CaSO}_{4}$, and $\mathrm{MgSO}_{4}$; treatment $4=8 \mathrm{lb} /$ yard ${ }^{3}$ lime and $0 \mathrm{lb} /$ yard ${ }^{3} \mathrm{CaSO}_{4}$ and $\mathrm{MgSO}_{4} ; \mathrm{llb} /$ yard ${ }^{3}=0.5933 \mathrm{~kg} \cdot \mathrm{m}^{-3}$.

${ }^{\mathrm{y}} \mathrm{l} \mathrm{g}=0.0353 \mathrm{oz}$.

${ }^{x}$ Means within columns (and within planting replication) followed by different letters are significantly different according to Duncan's multiple range test $(P \leq 0.05)$. 
consumer preference for bag size and label design as related to specialty vegetable medium.

\section{Literature cited}

Argo, W.R. and J.A. Biernbaum. 1996. The effect of lime, irrigation water source, and water-soluble fertilizer on root-zone $\mathrm{pH}$, electrical conductivity, and macronutrient management of container root medium with impatiens. J. Amer. Soc. Hort. Sci. 121:442-452.

Argo, W.R. and J.A. Biernbaum. 1997. The effect of root medium on root zone $\mathrm{pH}, \mathrm{Ca}$, and $\mathrm{Mg}$ management in containers with impatiens. J. Amer. Soc. Hort. Sci. 122:275-284.

Bauder, J.W., T.A. Bauder, R.M. Waskom, and T.F. Scherer. 2014. Assessing the suitability of water (quality) for irrigation-Salinity and sodium. Soil Sci. Soc. Amer. J. 56:1292-1298.

Biernbaum, J.A. 1994. A delicate balance. Greenhouse Grower 12(1):88-94.

Bilderback, T.E. 2001. Using the pourthru procedure for checking $\mathrm{Ec}$ and $\mathrm{pH}$ for nursery crops. NC State Univ. Hort. Info. Lflt. AG-717-W.

Dole, J.M. 1994. Irrigation, p. 24-27. In: M.L. Gaston, P.S. Konjoian, S.A. Carver, C.A. Buck, and R.A. Larson (eds.). Tips on growing and marketing hanging baskets. Ohio Florists' Assn., Columbus, OH.

Greenlee, L.F., D.F. Lawler, B.D. Freeman, B. Marrot, and P. Moulin. 2009. Reverse osmosis desalination: Water sources, technology, and today's challenges. Water Res. 43:2317-2348.

Handreck, K.A. and N.D. Black. 2002. Growing medium for ornamental plants and turf. 3rd ed. New South Wales Univ. Press, Kensington, Australia.

Ludwig, L.S. and J.C. Peterson. 1984. An assessment of the chemical properties of water from floriculture industry firms throughout Ohio and the United States. HortScience 19:521 (abstr.).

Nelson, P.V. 1998. Greenhouse operation and management. 5th ed. Prentice Hall, Upper Saddle River, NJ.

Peterson, J.C. and L.L. Kramer. 1991. Water quality, p. 31-33. In: H.K. Tayama and T.J. Roll (eds.). Tips on growing zonal geraniums. Ohio Florists' Assn., Columbus, $\mathrm{OH}$.

Valdez-Aguilar. 2004. Effect of alkalinity in irrigation water on selected greenhouse crops. Texas A\&M Univ., College Station, PhD Diss.

Wickerson, D.C., B.D. Drees, D. McWilliams, and J.M. Sweeten. 1996. Water management guidelines for the greenhouse industry. Texas Agr. Ext. Serv. B-5016.

Wright, R.D. 1986. The pour-through nutrient extraction procedure. HortScience 21:227-229.

Wright, A.N., A.X. Niemiera, J.R. Harris, and R.D. Wright. 1999. Preplant lime and micronutrient amendments to pine bark affect growth of seedlings of nine container-grown tree species. HortScience 34:669-673. 